\title{
Mesleki Tükenmişlik, Makyevelizm, Psikolojik Sözleşme İhlali ve Demokratik Liderlik Arasındaki İliş̧kilerin Smartpls ile Analizi
}

\section{Dr. Öğr. Üyesi Yavuz Kağan Yasım ${ }^{1^{*}}$}

Geliş tarihi: 28.11 .2019

Kabul tarihi: 31.12.2019

\section{Atıf bilgisi:}

IBAD Sosyal Bilimler Dergisi

Sayı: $6 \quad$ Sayfa: $87-101$

Yıl: 2020 Dönem: Kış

This article was checked by iThenticate. Similarity Index 07\%

Bu makalede araștırma ve yayın etiğine uyulmuştur.

1 Hitit Üniversitesi, Türkive, ykyasim@gmail.com

ORCID ID 0000-0002-3542-5493

${ }^{*}$ Sorumlu yazar
$\ddot{O} \mathrm{Z}$

$\mathrm{Bu}$ çalışmanın amacı, satış elemanlarının mesleki tükenmişlik, makyevelistlik, psikolojik sözleşme ihlali algısı ve liderlerinin demokratiklik düzeyi arasındaki ilişkileri incelemektir. Satış hedefleri ile çalışan personelin örgütsel tutumları, örgüt hedeflerine ulaşmada önemli bir kriterdir. Calıșmanın evrenini hızlı tüketim sektöründe çalışan satış personeli oluşturmaktadır. Bu amaçla Ankara'da çalışan 148 satıs elemanına anket uygulanmıștır. Anket verileri SmartPLS programı ile analiz edilmiştir. Gerekli koşulları taşımayan anket soruları elenerek analiz dışında tutulmuștur. Analiz sonucunda psikolojik sözleşme ihlali ile ahlaki yoksunluk, statü arzusu, diğerlerine güvensizlik, duygusal tükenme, duyarsılaşma ve demokratik liderlik arasında anlamlı ilişki bulunmuştur. Ayrıca demokratik liderlik ile statü arzusu, control arzusu, duygusal tükenme ve başarızılık hissi arasında da anlamlı ilişki tespit edilmiştir.

Anahtar Kelimeler: Makyevelizm, Psikolojik Sözleşme İhlali, Mesleki Tükenmişlik, Demokratik Liderlik, SmartPLS. 


\section{Analysis of Relationships Between Occupational Burnout, Machiavelism, Psychological Contract Breach, and Democratic Leadership}

Assist. Prof. Dr. Yavuz Kağan Yasım ${ }^{*}$

First received: 28.11 .2019

Accepted: 31.12 .2019

\section{Citation:}

IBAD Journal of Social Sciences

Issue: 6

Pages: $87-101$

Year: 2020

Session: Winter

This article was checked by iThenticate. Similarity Index 07\%

1 Hitit University, Turkey, ykyasim@gmail.com,

ORCID ID 0000-0002-3542-5493

\section{* Corresponding Author}

\begin{abstract}
The aim of this study is to identify the relationship between occupational burnout, machiavellism, psychological contract breach, and democratic leadership. Sales targets and person's organizational attitudes are key factors to achieve the organizational goals. The universe of the study consists of 148 sales personel working in the FMCG sector in Ankara. SmartPLS package program was used to analyze the data. Prior to analyzing the data set, the survey questions that do not match the required conditions were excluded from the analysis. As a result of the analysis, a significant relationship was found between the psychological contract breach and amoral manipulation, desire for status, distrust of others, emotional exhaustion, depersonalization and democratic leadership. In addition, a significant relationship was found between democratic leadership and desire for status, desire for control, emotional exhaustion and diminished personal accomplishment.
\end{abstract}

Keywords: . Machiavellism, Psychological Contract Breach, Occupational Burnout, Democratic Leadership, SmartPLS. 


\section{GíRIS}

2000'li yıllar birçok alanda önemli paradigma değişimlerinin yaşandığı yıllar olmaktadır. Bu değişimlerden biri de yönetim ve örgütsel davranış alanlarındadır. Teknolojinin birçok alanda standartlaşması ile yoğun rekabet ortamında başarı artık insan faktörüne bağlıdır. Dolayısıyla örgütsel yapı içinde liderinden çalışanına kadar tüm bireyler aynı yükü taşımakta ve birbirleriyle etkileşim içinde olmaktadırlar. Örgütsel çıktıları etkileyen bireysel ve örgütsel faktörler içiçe geçmiştir. Çalışanlar bir yandan yoğun rekabet ortamında stresle mücadele ederken, bir yandan da örgütle ilgili bir takım beklentiler taşımaktadırlar. Satışcılık, stres düzeyi en yükssek mesleklerden biri olarak kabul edilmektedir (Ercan ve Kazançoğlu, 2019, s. 6). Yüksek stres düzeyi ancak beklentilerin karşılanması halinde tolere edilebilir bir faktördür.

Çalışanların örgütten beklentilerini kısaca psikolojik sözleşme olarak ifade edebilmek mümkündür. $\mathrm{Bu}$ beklentilerin karşılanmaması halinde tükenmişlik yaşanması muhtemeldir. Tükenmişliğin özellikle de insanlarla yüz yüze çalış1lan mesleklerde ön plana çıkmış olduğu görülmektedir (Ertürk ve Keçecioğlu, 2012, s. 39). Müşterilerle yoğun iletişim içerisinde olan satış elemanları makyevelist tutum içerisine girerek en azından beklentilerinin bir kısmına daha kolay ulaşmayı tercih edebilmektedirler. Bu yapı içerisinde liderlerin tutumları da önemli bir belirleyicidir. Etik yönetim, liderlik, örgütsel politika ve işyerinde güvenliğin öneminin altını çizen çalışmalar, Makyevelizm'in yönetim çalışmalarında önemli bir ilgi alanı olması gerektiği ifade etmektedir (Dahling vd., 2008, s.2). Örgütsel ortamda bireysel farklı1ıkların rolünün daha iyi anlaşılması için kişiliğin karanlık yönü olarak ele alınan Makyavelizmin incelenmesi alanda önemli bir yer tutmaktadır (Özsoy ve Ardıç, 2017, s. 392). Makyevelizm, gevşek bir şekilde yapılandırılmış organizasyonlarda gelişir ve genellikle ekonomik şartlarla motive olur (Kroger vd., 2015, s. 86). Literatürde makyevelizm konusunda yapılan çalışmaların (Jaiswal ve Bhal, 2014; Shelby ve Chonko, 1984; Galie ve Bopst, 2006; Drory ve Gluskinos, 1980; Gemmill ve Heisler, 1972; Rehman ve Shahnawaz, 2018) yöneticiler üzerinde yoğunlaştığı görülmektedir. Bu çalışmada ise çalışanlar ele alınmıştır. Çalışanların makyevelistlik düzeyi özellikle satış şirketleri için önemlidir. Satış şirketleri, satış hedeflerinin tutturulması için çalışanlarına esnek koşullar sunmaktadır. Satış primleri bu koşullara tipik bir örnek oluşturmaktadır. Dolayısıyla mesleki tükenmişlik, makyevelizm, psikolojik sözleşme ihlali (PSi) ve liderlik türü arasındaki ilişkilerin incelenmesi literatüre önemli katkı sağlayacaktır.

\section{Literatür}

\subsection{Makyevelizm}

"Prens" (1513) adlı eserinde N. Machiavelli, etik ve değerlerini brrakabilecek siyasi liderlerin, bunu yapamayan liderlerden daha etkili olacağını ileri sürmektedir. Machiavelli'nin başkalarının nasıl yönetileceği konusundaki tavsiyesi uzun zamandır yönetim teorisyenlerinin ilgisini çekmiş ve tartışmalara konu olmuştur. Shelby ve Chonko, 1984'te "Machiavelli'nin on altınc1 yüzy1l İtalya'daki politik liderleri konu etmesine yazmasına rağmen, birçok analist bu fikirlerinin modern işletme yönetimi için geçerli olduğuna inandığını yazmıştır (Jackson ve Grace, 2018, s. 114). "Bugün, Machiavelli tarafindan tarif edilen özellikler seti, adını taşıyan bir kişilik özelliği olarak kabul edilmektedir (Zagenczyk vd., 2012, s. 287). Makyevelizm, sosyalleşme ve yaşam deneyimleri sürecinde zamanla gelişen bir kişilik özelliğidir (Kroger vd., 2015, s. 80). Dolayısıyla sadece yöneticiler için bir yöntemi ifade etmemekte, aynı zamanda çalışanlar için de hedeflere ulaşmada kullanılacak yöntemlerin bir belirleyicisi olmaktadır.

Makyavelizm bir kişilik özelliği olarak karşımıza çıkmakta ve örgütsel bağlamda birçok değişken ile ilişkileri bulunmaktadır (Ülbeği, 2006, s. 90). "Makyevelistler", başkalarını kendi amaçları için izleyen ve manipüle eden ve bu amaçlara ulaşmak için isteyerek suçluluk, aldatma ve hileyi kullanabilen sinik (alayc1) bireyler olarak kabul edilir (Shultz, 1993, s. 479).

Machiavelli "Amaca ulaşmak için kullanılacak her türlü araç mübahtır" fikrini literatüre kazandırmış ve bu felsefe "'Makyavelizm"' olarak isimlendirilmiştir (Geis ve Moon, 1981'den akt. Güney ve Mandacı, 2009, s. 84). Christie ve Geis (1970), Makyavelist bireylerin diğer bireylere faydacı bakış açısı ile yaklaştıklarını belirtmişlerdir. Aslında bu bireyler ahlaktan yoksun değil, sadece geleneksel ahlakla bağdaşmayan birtakım etik ilkelere göre hareket etmektedirler (Güney ve Mandac1, 2009, s. 85). 
Makyevelist düzeyi yüksek olan çalışanlar düşük olanlara göre ikna edici olmaya daha yatkın, öncülük etmeye daha motive ve daha karizmatiktirler. $\mathrm{Bu}$ durum bazı araştırmacılar tarafından, yüksek makyevelist anlayışa sahip olan çalışanların, işyerinde daha yüksek performans seviyelerine ulaşacaklarını iddia etmelerine neden olmaktadır. Öte yandan diğer araştırmacılar, makyevelist düzeyi yüksek bireylerin, empati eksikliği sergileme, işbirliğine göre firsatçllı̆ı tercih etme, işverenlerle ilişkilerini işlemsel bir şekilde görme, intikam alma ve olumlu karşılıkları görmeme nedeniyle, kuruluşlarına zarar verebileceğini ileri sürmektedirler (Zagenczyk vd., 2012, s. 288). Makyevelizm ekonomik olarak yıkıcıdır, çünkü kaçınılmaz olarak gizli suçlara yol açan aldatma, sahtekarlık ve yanlış beyanı ödüllendiren bir sisteme yol açar (Kroger vd., 2015, s. 83).

Makyevelizm, son dönemde 'karanlık üçlü"', olarak ifade edilen kişilik özelliklerinden birisi olarak uluslararası literatürde sıklıkla tartışılmaktadır. Makyevelist davranış potansiyel olarak yıkıcı olabilse de olumlu yönde yönlendirilebilmesi mümkündür (Kroger vd., 2015, s. 80).

\subsection{Mesleki Tükenmişlik}

Tükenmişlik kelimesi, 1970'li yıllarda Amerika'da, hizmet sektöründe çalışan insanların yaşadıkları mesleki bunalımı açıklamak için kullanılmış ve kavram ilk olarak 1974 yılında Freudenberger tarafından tanımlanmıştır (Sürgevil, 2006, s. 3). Bakker vd. (2004, s. 84) tükenmişliği; işle ilgili negatif deneyimlerin sonucu ortaya çıkan bir sendrom olarak kavramlaştırmışlardır. Tükenmişlik, yapılan işe, hayata ve diğer diğer insanlara karşı olumsuz tutumlara neden olan bir sendromdur. Bu durum özellikle işi gereği yoğun duygusal taleplere maruz kalan ve sürekli diğer insanlarla yüz yüze çalışmak durumunda olan kişilerde görülen fiziksel bitkinlik, uzun süreli yorgunluk çaresizlik ve umutsuzluk duygularının bir sonucudur. (Maslach ve Jackson, 1981, s. 99).

Maslach ve Jackson tükenmişliği üç alt boyutta tanımlamıştır. (Maslach ve Jackson, 1981, s. 99). Birinci alt boyut olan duygusal tükenme (TD) (emotional exhaustion); tükenmişliğin bireysel ve stres boyutunu belirtmektedir. Duygusal olarak tükenenlerin duygusal ve fiziksel kaynaklarında azalma meydana gelmektedir. İkinci alt boyut olan duyarsızlaşma (TDY) (depersonalizasyon) ise çalışanların hizmet verdikleri kişilere birer nesne gibi davranması, küçültücü sözler sarfetmesi, umursamaz alaycı bir tutum sergilemelerini ifade etmektedir. Kişinin çalıştı̆̆ işle ilgili olarak kendisini olumsuz bir şekilde değerlendirmesi ve başarısızlık hissi olarak tanımlanan kişisel başarıda azalma (TB) (diminished personal accomplishment), tükenmişliğin üçüncü alt boyutunu oluşturmaktadır.

Tükenmişliğin azalan verimlilik düzeyi ve yüksek istifa oranı gibi ciddi sosyo-ekonomik etkileri vardır (Golonka vd., 2019, s. 230). Tükenmişlik psikolojik bir gerginlik biçimidir ve azalan iş performansı, iş tatminsizliği, azalan müssteri memnuniyeti, düşük kurumsal bağlılık seviyeleri ve artan devamsızlık gibi istenmeyen sonuçlara yol açar (Babakus, vd., 2010, s. 18).

\subsection{Liderlik}

Liderlik, bir grubun ve ortak amaçların varlığı ile ortaya çıkan ve anlam kazanan bir etkileme sürecidir. Liderlik insanın tarih sahnesinde yerini almasıyla birlikte ortaya çıksa da, akademik manada kullanılmaya başlanması 19. yüzyılın ilk yarısından sonra olmuştur. Örgütlerde insan faktörünün önem kazanması ile birlikte liderlik konusu, hem yönetim hem de davranış bilimlerinde önemli bir çalışma alanı haline gelmiştir. Liderliğin ne olduğunu açıklamaya çalışan üç temel yaklaşım bulunmaktadır: Bunlar, özellikler yaklaşımı, davranışsal yaklaşımlar ve durumsal yaklaşımlardır (Küçüközkan, 2015, s. 88). Davranışsal yaklaşımda liderin özellikleri arka plana atılmış ve bunun yerine grup üyelerine, karşı gösterdiği davranışlar üzerinde yoğunlaşılmıştır. Liderin astları ile haberleşme şekli, yetki devredip etmemesi, planlama ve kontrol şekli, amaçları belirleme şekli v.b. davranışları lider etkinliğini belirleyen önemli faktörler olarak ele alınmıştır (Koçel, 2005, s. 428). Literatür incelendiğinde bu konuda yapılan çalışmaların başında McGregor'un ortaya koyduğu X ve Y yaklaşımı gelmektedir. X yaklaşımına göre; liderler otoriterdir ve tüm kontrolü ellerinde tutmak isterler. Y yaklaşımına göre ise, liderler demokratiktir. $\mathrm{Bu}$ liderler çalışanlarını kararlara katmak konusunda isteklidirler. Bu yüzden onlara danışır ve fikir alışverişinde bulunurlar. Demokratik-Katılımcı Liderlik Davranışı Yaklaşımı daha çok, demokratik ve insanın merkeze alındığı organizasyonlarda görülmektedir. Bu liderlik tarzı ile daha etkin

\footnotetext{
${ }^{1}$ Makyevelizm, Narzism ve Psikopati
} 
ve sağlıklı kararlar alınması, fikirlerine değer verilen üyelerin işlerinden tatmin sağlamaları, böylece daha etkin ve verimli çalışan bir grup elde edilmesi mümkündür (Küçüközkan, 2015, s. 99). Liderler örgütlerin başarısındaki temel girdilerdendir. Günümüzde yönetim alanında yapılan çalışmaların vizyoner liderlik, dönüşümsel liderlik, işlemsel liderlik, güçlendirici liderlik, hizmetkar liderlik gibi çağdaş liderlik yaklaşımları çerçevesinde yürütüldüğü görülmektedir.

Bu çalışmada Iowa Üniversitesinde Kurt Levin ve arkadaşları tarafindan yapılan araştırmalar sonucunda ortaya konan Demokratik, otokratik ve serbestiyetçi liderlik tarzlarından, demokratik lider (LD) tipi dikkate alınmıştır.

\subsection{Psikolojik Sözleşme İhlali:}

Psikolojik sözleşme, bireyin herhangi bir mübadele ilișkisinde, bu ilişkinin koşullarına yönelik inançlarını ifade etmektedir. Psikolojik sözleşme, işveren ve işgörenler arasındaki sorumluluklara, beklentilere ilişkin oluşan yazılı olmayan ve karşılıklı güvene dayalı soyut ve duygusal bir bağa dayalı sözleşmedir. Psikolojik sözleşme teorisine göre, çalışanların kurumun kendilerine eğitim, promosyonlar, iş güvenliği veya yazılı sözleşmelerde açıkça tanımlanmayan herhangi bir faktörle ilgili olarak verildiğine inandıkları yazılı olmayan sözler, çalışanların algılarını şekillendirmede önemli bir rol oynamaktadır. Araştırmacılar psikolojik sözleşme vaatlerinin (veya algılanan yükümlülüklerin) genellikle çalışanların örgütle erken deneyimleri sırasında, çoğu kez erken ilişkiye girilen işverenlerle ve örgüt üyeleriyle ilgili deneyimlerin bir sonucu olarak gelişmeye başladığını öne sürmektedirler (Rousseau, 1995). Psikolojik sözleşme ihlali bir kuruluşun, psikolojik sözleşme dahilindeki bir ya da birkaç yükümlülüğünü çalışanların katkısına orantılı olarak yerine getirmemesi olarak tanımlanmıştır (Morrison ve Robinson, 1997). Psikolojik sözleşme ihlalinin sonuçlarını açıklamak için sıklıkla iki teori kullanılmaktadır. Bunlar "'sosyal değişim teorisi" ve "karşılıklılık normu'dur. Sosyal değişim teorisine göre, kurumun çalışanlarının psikolojik sözleşmelerini yerine getirmeleri, çalışanlarda kurumun hedeflerine ulaşmasına yardımcı olma yükümlülüğ̈̈ duyguları yaratır. Bu iddianın kilit noktası Goulder (1960)'ın olumlu karşılıklılık kuralıdır. Bu bireylere, kendilerine yardım eden kişilere yardım etmelerini zorunlu kılan genelleştirilmiş bir ahlaki kuraldır (Zagenczyk vd., 2012, s. 289).

1994 yılında Robinson, psikolojik sözleşmenin, çalışanın çalışma tutumunu ve çalışma davranışını biçimlendirmede belirleyici bir faktör olduğunu ifade etmiştir. 1990'da ise Rousseau, psikolojik sözleşmenin ihlalinin (PSI) güçlü duygusal değişime neden olacağı ve çalışanların performansında düşme, işin yavaşlatılması, işe gelmeme ve istifaya neden olan kızgınlığa sebep olacağını ifade etmiş̧ir (Cai ve Ye: 2016).

\section{ARAȘTIRMA MODELI}

\subsection{Kavramsal Model ve Hipotezler}

Sakalaki vd. (2007), makyevelizm ile ekonomik çıkarcılık (opportunism) arasındaki ilişkiyi incelediği çalışmasında, yüksek düzeyde makyevelist olanların çok daha fazla opportunist olduklarını tespit etmiştir. Satış elemanları genellikle satışları üzerinden primle çalışmaktadırlar. Dolayısıyla bu çalışanlardan ekonomik çıkarcılık beklemek yanlış olmayacaktır. Zagenczyk vd. (2012, s. 288) mevcut örgütsel çevrenin yüksek Makyevelist çalışanların olumsuz özelliklerini daha belirgin hale getireceğini savunmaktadır. Dolayısıyla psikolojik sözleşme ihlali algısı, liderin otokratik tutumları ve mesleki tükenmişlik algısı çalışanların olumsuz makyevelist tutumlar sergilemelerine neden olacaktır. Shultz (1993) satış temsilcilerinin makyevelistlik düzeyi ile satış başarısı arasındaki ilişkiyi analiz eden çalışmasında organizasyon yapısının önemli olduğunu tespit etmiştir. Satış temsilcilerinin kendileri için ödül çıktısını artırma firsatı yaratacak şekilde hile yapmasına imkan veren gevşek yapılandırılmış örgütlerde, yüksek makyevelist düzeye sahip çalışanların daha iyi performans gösterdiği görülmüştür. Böyle yöntemlere imkan vermeyen sıkı yapılandırılmış örgütlerde ise düşük makyevelist düzeyli çalışanların performans düzeyi daha yüksek bulunmuştur (Shultz, 1993, s. 492). Ayrıca Özsoy ve Ardıç (2017), çalışmalarında makyevelizm ile iş tatmini arasında negatif yönlü anlamlı ilişki tespit etmiş̧erdir. Olumsuz örgütsel çıtılara neden olan bir diğer sorun alanı olan mesleki tükenmişlik ile makyevelizm arasında da pozitif yönlü anlamlı ilişki (Mirkovic ve Bianchi, 2019, s. 30) vardır.

Yapılan çalışmalar (Avşaroğlu vd., 2005; Gündüz vd., 2013; Polat ve Uğurlu, 2009; Demir, 2018) mesleki tükenmişlik ile olumlu tutum ve davranışlar arasında negatif yönlü, olumsuz tutum ve 
davranışlarla ise pozitif yönlü anlamlı ilişkinin bulunduğunu göstermektedir. Tükenmişliği ortaya çıkaran bireysel faktörlerden biri bireylerin beklentilerinin karşılanamamasıdır (Telli, vd. 2012, s. 137). Dolayısıyla Psikolojik sözleşme ihlali algısı tükenmişliğe sebep olabilmektedir. PSİ ile tükenmişlik ve alt boyutları arasında pozitif yönlü anlamlı ilişki vardır (Salha vd., 2017, s. 55).

Literatür incelendiğinde liderlik türünün de tükenmişlik üzerinde etkili olduğu görülmektedir. Babakus vd., (2010) hizmetkar liderlerin tükenmişliği önemli ölçüde azalttığını tespit etmiştir. Katılımcı liderliğin duygusal tükenmeyi önemli ölçüde azalttığını belirleyen Mulki, Jaramillo ve Locander (2006) tarafindan yapılan çalışma dışında, tükenmişlik sürecindeki liderlik stillerinin rolü konusunda araştırma eksikliği bulunmaktadır (Babakus vd., 2010, s. 21). Hunsaker (2019), manevi liderlik ile tükenmişlik arasında negatif yönlü anlamlı ilişki tespit etmiştir. Salem (2015) ise dönüşümsel liderlik ile tükenmişlik arasında negatif yönlü anlamlı ilişki tespit etmiştir. Bobbio vd. (2012) güçlendirici liderlik ile lidere güven arasındaki güçlü pozitif ilişkiden yola çıkarak, lidere güvenin çalışanların duygusal tükenme ve mesleki tükenmişliklerine negatif etkilerinin olduğunu belirtmiştir. Adıgüzel (2019) çalışmasında despotik liderliğin iş tatminini olumsuz yönde etkilediğini, işten ayrılma niyetini artırdığını tespit etmiştir. Başka bir çalışmada (Ece, 2019) yöneticilerin hizmetkar liderlik davranışının çalışanların işe yönelik tutumlarını olumlu yönde etkilediği ve bununda çalışanların işten ayrılma niyetini azalttığı tespit edilmiştir. Telli vd. (2012) ise çalışmalarında, otokratik liderlik ile duygusal tükenme ve kişisel başarısızlık hissi arasında pozitif yönlü anlamlı ilişki tespit etmişlerdir.

\subsection{Araştırmanın Modeli}

Bu çalışmanın amacı, yüksek stres düzeyine sahip olan satış elemanlarının mesleki tükenmişlik düzeyi, psikolojik sözleşme ihlali algıları ve makyevelistlik düzeyleri ile liderlerin demokratikliği arasındaki ilişkiyi tespit etmektir. Literatür incelemesi sonucunda araştırmanın modeli ve hipotezleri aşağıdaki şekilde oluşturulmuştur.

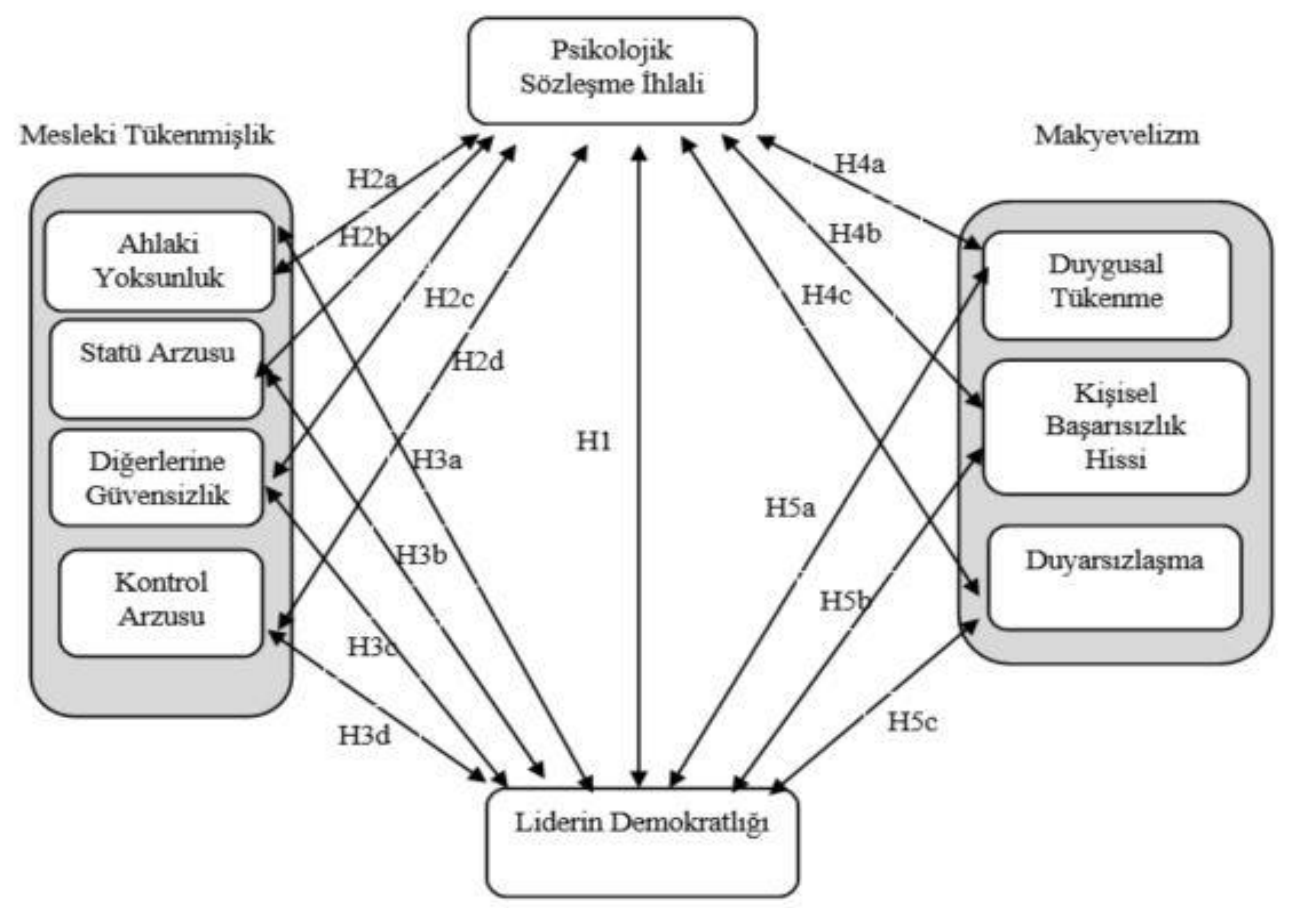

H1. PSİ ile LD arasında negatif yönlü anlamlı ilişki vardır.

H2. Makyevelizmin alt boyutları ile PSİ arasında pozitif yönlü anlamlı ilişki vardır.

H3. Makyevelizmin alt boyutları ile LD arasında negatif yönlü anlamlı ilişki vardır.

H4. PSİ ile mesleki tükenmişliğin alt boyutları arasında pozitif yönlü anlamlı ilişki vardır.

H5. LD ile mesleki tükenmişliğin alt boyutları arasında negatif yönlü anlamlı ilişki vardır. 


\subsection{Araștırmanın Yöntemi}

$\mathrm{Bu}$ çalışmada hipotezleri test etmek için yapısal eşitlik modellemesi (SEM) kullanılacaktır. Yapısal eşitlik modellemesi, çeşitli disiplinlerde en göze çarpan araştırma yöntemlerinden biridir. Ölçüm hatalarını hesaplarken birden fazla değişken tarafından temsil edilen yapı kümeleri arasındaki bir dizi karşılıklı bağımlılık ilişkisini aynı anda inceleme yeteneği, SEM'e yaygın olarak başvurulmasına katkıda bulunmuştur. $\mathrm{Bu}$ amaçla kullanılan farklı yöntemler arasında yapısal eşitlik modellemesi, özellikle uluslararası yönetim, pazarlama, stratejik yönetim, davranış bilimleri, örgüt gibi alanlarda açık ara en belirgin yöntemdir (Ali, vd., 2018, s. 515; Kwong ve Wong, 2013). SEM'e yönelik birkaç farklı yaklaşım vardır: IIlk yaklaşım, AMOS, EQS, LISREL ve MPlus gibi yazılım paketleri kullanılarak yaygın olarak uygulanan Kovaryans bazlı SEM (CB-SEM)' dır. İkinci yaklaşım, varyans analizine odaklanan ve PLSGraph, VisualPLS, SmartPLS ve WarpPLS kullanılarak yapılabilecek Kısmi En Küçük Kareler (PLS)'dir. SmartPLS, Kısmi En Küçük Kareler Yapısal Eşitlik Modellemesi (PLS-SEM) için önde gelen yazılım uygulamalarından biridir (Kwong ve Wong, 2013, s. 2). Bu çalışmada analiz aracı olarak SmartPLS kullanılmıştır.

SmartPLS özellikle normal dağılıma sahip olmayan küçük örneklem grupları için tercih edilmesi gereken bir yöntemdir. Ayrıca ileri sürülen yeni davranış kalıpları arasındaki ilişkiyi açılamaya yöneliktir (Dülgeroğlu ve Başol, 2017, s. 296). Bu çalışmada da satış baskısı sonucu ortaya çıkabilecek makyevelist tutum, mesleki tükenmişlik ve liderin demokratikliği ile psikolojik sözleşme ihlali algıs1 arasındaki ilişki açıklanmaya çalışılmışıı. Çalışmanın evrenini Ankara ilinde FMSC (Hızlı Tüketim) sektöründe çalışan satış elemanları oluşturmaktadır. Ankara'da gıda ve temizlik ürünlerinin toptan satışında önemli bir paya sahip olan GIMAT bölgesinde çalışan satış elemanlarına ölçekler dağıtılmış, doldurulan anketlerden 5 adeti geçersiz sayılmış ve 148 'i değerlendirmeye değer bulunmuştur.

\section{4. Ölçekler}

Makyavelizm Ölçeği: Dahling vd. (2009) yeni bir Makyavelizm ölçeği geliştirerek alan yazına kazandırmışlardır. Makyavelist Kişilik Ölçeği olarak ifade edilen bu aracın batı yazınında farklı örneklemlerde güvenirlik ve geçerlik çalışmalarının yapıldığı görülmektedir. Dahling, vd. (2009) tarafından hazırlanan ölçeğin Türkçe güvenilirlik ve geçerlilik çalışması Ülbeği (2016) tarafından yapılmıştır. Ölçek "ahlaki yoksunluk", "diğerlerine güvensizlik", "kontrol arzusu" ve "statü arzusu" olmak üzere dört alt boyuttan oluşmaktadır. Ölçekte toplam 16 soru bulunmaktadır.

Liderlik Tarzı Ölçeği: Clark'ın (1998) geliştirdiği Bayyurt ve Kılıç (2017) tarafından kullanılan liderlik ölçeğinin demokratik liderlik algılarına yönelik boyutu kullanılmıştır. Ölçekte 10 soru bulunmaktadır.

Tükenmişlik Ölçeği: Maslach ve Jackson (1981) tarafından geliştirilen ve Türkçe uyarlaması ve geçerlilik-güvenilirlik çalışması Ergin (1992) tarafından yapılmış olan Maslach Tükenmişlik Ölçeği (Maslach Burnout Inventory- MBI)' nin Ercan ve Kazançoğlu (2019) tarafından satış elemanlarına yönelik düzenlenmiş formu kullanılmıştır.

Psikolojik Sözleşme İhlali Algısı: Robinson ve Rousseau (1994) tarafindan geliştirilmiş psikolojik sözleşme ihlali ölçeğinin kısaltılmış formu kullanılmıştır. Ölçekte 3 soru yer almaktadır.

\subsection{Analiz Sonuçları}

Ölçeklere ait tanımlayıcı istatistikler tablo 1' de yer almaktadır.

Tablo 1: Tanımlayıcı Ístatistikler

\begin{tabular}{|c|c|c|c|c|c|}
\hline Ölçekler & Ort. & Std. Sapma & Ölçekler & Ort. & Std. Sapma \\
\hline Ahlaki Yoksunluk & 1,48 & 0,92 & Duyarsızlaşma & 2,13 & 1,09 \\
\hline Statü Arzusu & 3,61 & 1,28 & Duygusal Tükenme & 2,30 & 1,26 \\
\hline Diğerlerine Güvensizlik & 2,57 & 1,24 & Başarısızlık Hissi & 1,70 & 0,92 \\
\hline Kontrol Arzusu & 3,14 & 1,49 & Tükenmişlik & 1,99 & 1,00 \\
\hline Makyevelizm & 2,30 & 1,04 & Liderin Demok. & 3,88 & 1,12 \\
\hline P.Sözleşme İhl. & 2,04 & 1,27 & & & \\
\hline
\end{tabular}


Kurulan model SPSS ve SmartPLS programları ile analiz edilmiştir. Yapılan Kolmogorov-Smirnov normallik testinde ölçeklerin normallik varsayımını karşılamadığ 1 (sig. $<0,05)$ görülmüştür. Verilerin normal dağılmadığı varsayımından hareketle analiz için Kısmi En Küçük Kareler Yapısal Eşitlik Modellemesi yöntemi kullanılmıştır. Araştırmada örneklem sayısı 148, bootstrapping olarak 5000 sayıs1 belirlenmiştir. Yapılan analizde ' $t$ ' değeri 1,96'ın altında kalan maddeler anlamsızlığından dolayı sırayla modelden çıkarılmış ve analiz tekrar yapılmıştır. Model tahmin edildikten sonra yapılan ölçümde tüm $\mathrm{t}$ değerleri 1,96 'in üzerinde çıkmıştır.

Daha sonra ilişkilerin anlamlı olması üzerine ölçek maddelerin yüklerine bakılmıştır. Ölçüm modelinde standardize edilmiş katsayısı $0,70^{\prime}$ in altında olan maddeler en düşükten başlayarak modelden çıkarılmıştır. Bunlar sırasıyla MA1, MA4, MD1, MDC2, TD5, L18, LD19, TDY4, MA5, MD2, PS2, TB1, TD2, L20 maddeleridir. Çıkarılan maddelere ilişkin sorular tablo 2' de yer almaktadır.

Tablo 2: Modelden Çıarılan Sorular

\begin{tabular}{|l|l|}
\hline MA1 & Başarıya ulaşmamda yardımcı olacağına inanırsam etik davranmaya önem vermem. \\
\hline MA4 & Diğerlerine karşı rekabet avantajını sürdürmek için yalan söylemenin gerekli olduğuna inanırım. \\
\hline MA5 & Diğerleriyle konuşmanın tek iyi sebebi, kendi yararıma kullanabilecek bilgi almaktır. \\
\hline MD1 & İnsanlar yalnızca kişisel çıkarla motive olur. \\
\hline MD2 & Gruplara katılmaktan hoşlanmam çünkü diğerlerine güvenmem. \\
\hline MDC2 & Durumu kontrol altında tutmaktan hoşlanırım. \\
\hline L18 & Yöneticim astların yetiştirilmesinde liderlik gücünü kullanmaktan hoşlanır. \\
\hline L19 & Yöneticim çalışanların amaçları belirlenirse, kendi kendilerini yönetebileceğine inanır. \\
\hline L20 & $\begin{array}{l}\text { Yöneticim çalışanların, örgütsel problemlerin çözümü için yaratıcılıklarını ve yeteneklerini nasıl } \\
\text { kullanacaklarını bildiklerine inanır. }\end{array}$ \\
\hline TD2 & İsününün sonunda kendimi bitkin hissediyorum. \\
\hline TD5 & Kendimi işimde çok enerjik hissediyorum. \\
\hline TB1 & Bu işte kayda değer birçok başarı elde ettim. \\
\hline TDY4 & Müşterilerin bazı problemleri için beni suçladığını hissediyorum. \\
\hline PS2 & Çalıştığım kurum bana verilen sözlerin tamamını tutmuştur. \\
\hline
\end{tabular}

Revize modelde faktörlerin madde yükleri aşağıdaki gibi oluşmuştur.

Tablo 3: Ölçeklerin Güvenilirlik İstatistikleri ve Faktör Yükleri

\begin{tabular}{|c|c|c|c|c|}
\hline FAKTÖRLER & MADDELER & $\begin{array}{l}\text { MADDE } \\
\text { YÜKLERİ }\end{array}$ & $\begin{array}{c}\text { Birleşik } \\
\text { Güvenirlik }\end{array}$ & $\begin{array}{c}\text { İçsel Tutarlılık (C. } \\
\text { Alpha) }\end{array}$ \\
\hline \multirow{7}{*}{$\begin{array}{l}\text { Demokratik Liderlik } \\
\text { (DEMLIDER) }\end{array}$} & L11 & 0,8307 & \multirow{7}{*}{0,9312} & \multirow{7}{*}{0,9137} \\
\hline & L12 & 0,7204 & & \\
\hline & $\mathrm{L} 13$ & 0,8223 & & \\
\hline & L14 & 0,8295 & & \\
\hline & L15 & 0,8393 & & \\
\hline & L16 & 0,8208 & & \\
\hline & L17 & 0,8152 & & \\
\hline \multirow{2}{*}{ Ahlaki Yoksunluk (MA) } & MA2 & 0,9231 & \multirow{2}{*}{0,8622} & \multirow{2}{*}{0,6929} \\
\hline & MA3 & 0,8155 & & \\
\hline \multirow{3}{*}{ Diğerlerine Güvensizlik (MD) } & MD3 & 0,817 & \multirow{3}{*}{0,8667} & \multirow{3}{*}{0,7797} \\
\hline & MD4 & 0,7877 & & \\
\hline & MD5 & 0,8752 & & \\
\hline \multirow{2}{*}{ Kontrol Arzusu (MDC) } & MDC1 & 0,834 & \multirow{2}{*}{0,8589} & \multirow{2}{*}{0,6760} \\
\hline & MDC3 & 0,9002 & & \\
\hline \multirow{3}{*}{ Statü Arzusu (MS) } & MS1 & 0,8723 & \multirow{3}{*}{0,8451} & \multirow{3}{*}{0,7266} \\
\hline & MS2 & 0,7287 & & \\
\hline & MS3 & 0,8046 & & \\
\hline Psikolojik Söz. İhlali & PS1 & 0,8906 & 0,8860 & 0,7426 \\
\hline
\end{tabular}




\begin{tabular}{|c|c|c|c|c|}
\hline (PSOZİHL) & PS3 & 0,8930 & & \\
\hline \multirow{4}{*}{ Kişisel Başarısızlık Hissi (TB) } & TB2 & 0,818 & \multirow{4}{*}{0,8785} & \multirow{4}{*}{0,8171} \\
\hline & TB3 & 0,8064 & & \\
\hline & TB4 & 0,7909 & & \\
\hline & TB5 & 0,7939 & & \\
\hline \multirow{5}{*}{ Duygusal Tükenme (TD) } & TD1 & 0,7353 & \multirow{5}{*}{0,8914} & \multirow{5}{*}{0,8505} \\
\hline & TD3 & 0,8163 & & \\
\hline & TD4 & 0,841 & & \\
\hline & TD6 & 0,7589 & & \\
\hline & TD7 & 0,7869 & & \\
\hline \multirow{3}{*}{ Duyarsızlaşma (TDY) } & TDY1 & 0,7658 & \multirow{3}{*}{0,8273} & \multirow{3}{*}{0,6920} \\
\hline & TDY2 & 0,76 & & \\
\hline & TDY3 & 0,8257 & & \\
\hline
\end{tabular}

Tablo 3, SmartPLS programında ileri sürülen yapısal eşitlik modellemesinde sağlanması gereken madde ve yap1 güvenirliği değerlerini göstermektedir. Buna göre; madde güvenirlik değerlerinin 0,40 ' $1 \mathrm{n}$ üzerinde olması, ayrıca yapı güvenirlik değerlerinin de 0,70 'den büyük olması beklenmektedir. Analiz sonuçlarına göre genel olarak bu değerler sağlanmıştır. Sadece "Ahlaki Yoksunluk", 'Kontrol Arzusu", ve 'Duyarsızlaşma"' ölçeklerinin güvenilirlik değerleri 0,70'in altında kalmaktadır. Bazı araştırmacılar Cronbach Alpha yerine Birleşik Güvenilirlik (BG) kullanmayı tercih etmektedirler. C. Alpha, gerçek güvenilirliği hafife alan alt sınır değeri için eleştirilmektedir. BG değeri, C. Alpha'dan biraz daha yüksek olduğu için alternative olarak kullanılabilir. Çünkü aralarındaki fark nispeten önemsizdir (Peterson ve Kim, 2013, s. 197). Nitekim Lyberg vd. (1997) PLS yönteminde C. Alpha değerinin ,60'ın üzerinde olmasını güvenilirlik için yeterli görmüştür. Dolayısıyla sonuçlar, ileri sürülen madde ve faktör yapısının analize uygun olduğunu göstermektedir.

Tablo 4: İçsel Tutarlılık ve Güvenilirlik İstatistikleri

\begin{tabular}{|c|c|c|c|c|c|c|c|c|c|c|}
\hline \multirow[b]{2}{*}{ Faktörler } & \multirow[b]{2}{*}{ AVE } & \multicolumn{9}{|c|}{ Fornell- Larcker } \\
\hline & & DL & MA & MD & MDC & MS & PSİ & TB & TD & TDY \\
\hline DL & 0,6594 & 0.8120 & & & & & & & & \\
\hline MA & 0,7585 & $-0,1775$ & $0.8709 *$ & & & & & & & \\
\hline MD & 0,6847 & $-0,4169$ & 0,2124 & $0.8274 *$ & & & & & & \\
\hline MDC & 0,7530 & 0,2396 & 0,0858 & 0,0775 & $0.8677 *$ & & & & & \\
\hline MS & 0,6464 & 0,2471 & $-0,0136$ & 0,1021 & 0,4086 & $0.8039 *$ & & & & \\
\hline PSİ & 0,7953 & $-0,5560$ & 0,3382 & 0,3727 & $-0,1367$ & 0,0164 & $0.8917 *$ & & & \\
\hline TB & 0,6438 & $-0,5204$ & 0,3828 & 0,1352 & $-0,1470$ & $-0,2681$ & 0,3622 & $0.8023 *$ & & \\
\hline TD & 0,6219 & $-0,4010$ & 0,3279 & 0,3304 & $-0,0539$ & $-0,1362$ & 0,3798 & 0,3249 & 0.7886* & \\
\hline TDY & 0,6153 & $-0,1959$ & 0,4411 & 0,2535 & 0,1418 & 0,0504 & 0,4167 & 0,3115 & 0,5201 & $0.7844 *$ \\
\hline
\end{tabular}

- AVE değerinin karekök alınmış halidir.

Tablo 5, SmartPLS programında ileri sürülen yapısal eşitlik modellemesinde sağlanması gereken AVE değerlerini ve bu değerlere ilişkin karşılaştırmalı AVE karekök değerlerini göstermektedir. Buna göre; AVE değerlerinin 0,50'den büyük olması (Bagozzi ve Yi, 1988) ve AVE değerlerine ilişkin değerlerin kareköklerinin de ilgili sütundaki korelasyon değerlerinden büyük olması (Fornell ve Larcker, 1981) ileri sürülen modelin geçerli bir model olduğunu göstermektedir.

Yapılan analizde modele ilişkin tüm AVE değerlerinin 0,50'den büyük olduğu görülmüştür. Ayrıca AVE'nin karekök değerinin ilgili sütündaki korelasyon değerlerinden büyük olması ile istenilen FornellLarcker kriteri de sağlanmıştır. Sonuçlar modelin analize tabi tutulabileceğini göstermektedir. 


\section{Şekil 1: Modele İlişkin T Değerleri}

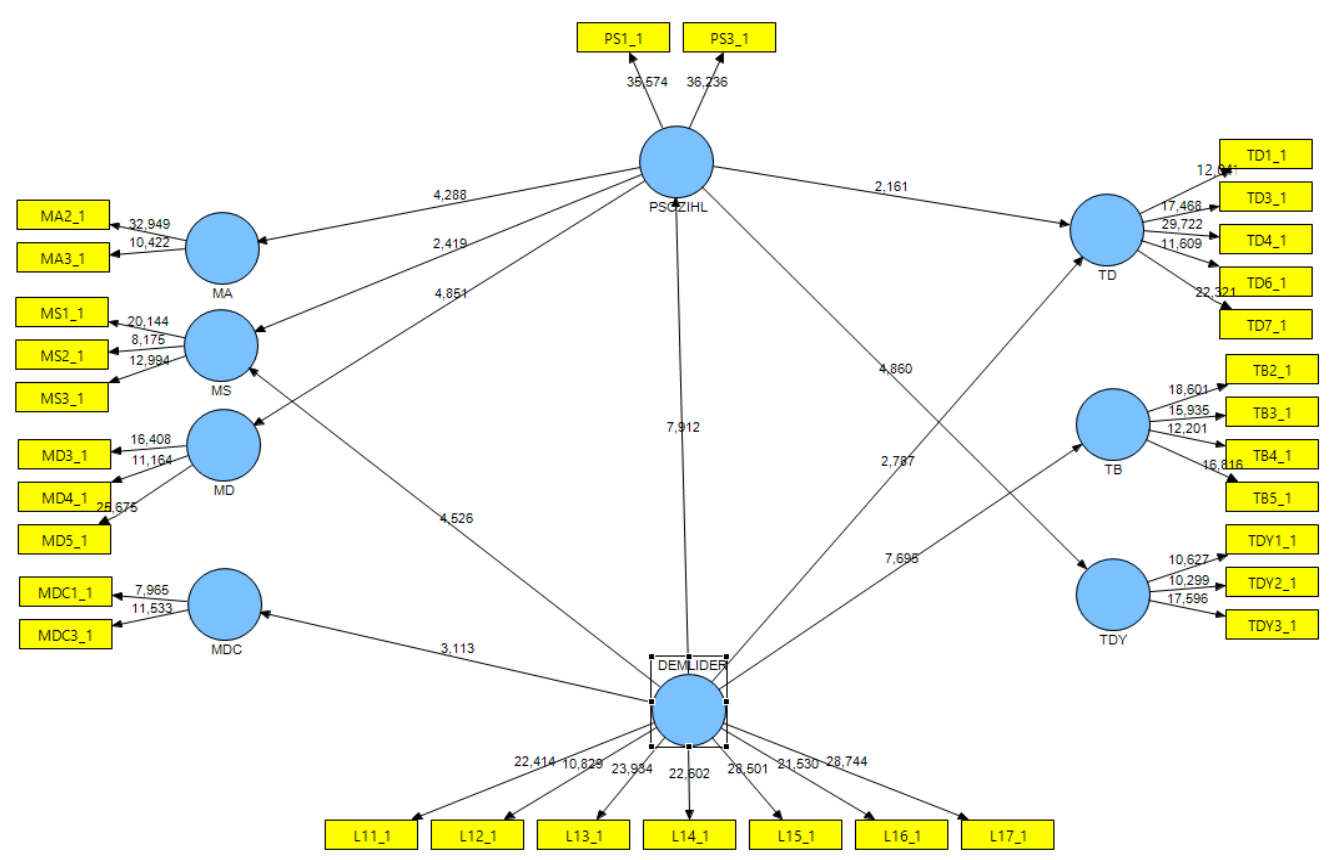

Şekil 1, ileri sürülen modele ilişkin "t” değerlerini göstermektedir. SmartPLS programında iki değiş̧ken arasında ileri sürülen yolun anlamlı olması için " $\mathrm{t}$ " değerinin 1,96 değerinden büyük olmas1 gerekmektedir. Aksi halde ileri sürülen yol anlamlı bir yol olarak değerlendirilmemektedir (Dülgeroğlu ve Başol, 2017, s. 299). Bu bağlamda model incelendiğinde Psikolojik sözleşme ihlali ile ahlaki yoksunluk (t: 4,288), statü arzusu (t: 2,419), diğerlerine güvensizlik (t: 4,851), duygusal tükenme (t: $2,161)$, duyarsızlaşma (t: 4,860) ve demokratik liderlik arasında anlamlı bir ilişki bulunmaktadır. Ayrıca demokratik liderlik ile statü arzusu (t: 4,526), kontrol arzusu (t: 3,113), duygusal tükenme (t: 2,787) ve kişisel başarısızlık hissi $(\mathrm{t}: 7,698)$ arasında da anlamlı ilişki bulunmaktadır.

$\mathrm{Bu}$ ilişkiler dışındaki değişkenler arasında anlamlı ilişsi bulunmamaktadır. Modele ilişkin katsayı değerleri şekil 2'de yer almaktadır. Şekil 2, değişkenler arasındaki ilişkilerinin yönünü ve kuvvetini göstermektedir. Analiz sonuçlarına göre ileri sürülen modele ilişkin yol katsayıları şu şekilde oluşmuştur.

Psikolojik Sözleşme İhlali
Psikolojik Sözleşme İhlali
Psikolojik Sözleşme İhlali
Psikolojik Sözleşme İhlali
Psikolojik Sözleşme İhlali
Psikolojik Sözleşme İhlali
Demokratik Liderlik
Demokratik Liderlik
Demokratik Liderlik
Demokratik Liderlik

Psikolojik Sözleşme İhlali

\section{$>$ Ahlaki Yoksunluk}

$>$ Statü Arzusu

r Katsayısı

$>$ Diğerlerine Güvensizlik

$>$ Duygusal Tükenme

$>$ Duyarsılaşma

$>$ Demokratik Liderlik.

$>$ Statü Arzusu

$>$ Kontrol Arzusu

$>$ Duygusal Tükenme

> Başarısızlık Hissi
0,338

0,223

0,373

0,227

0,417

$-0,556$

0,371

0,240

$-0,275$

$-0,520$ 


\section{Şekil 2: Modele İlişkin Katsayl Değerleri}

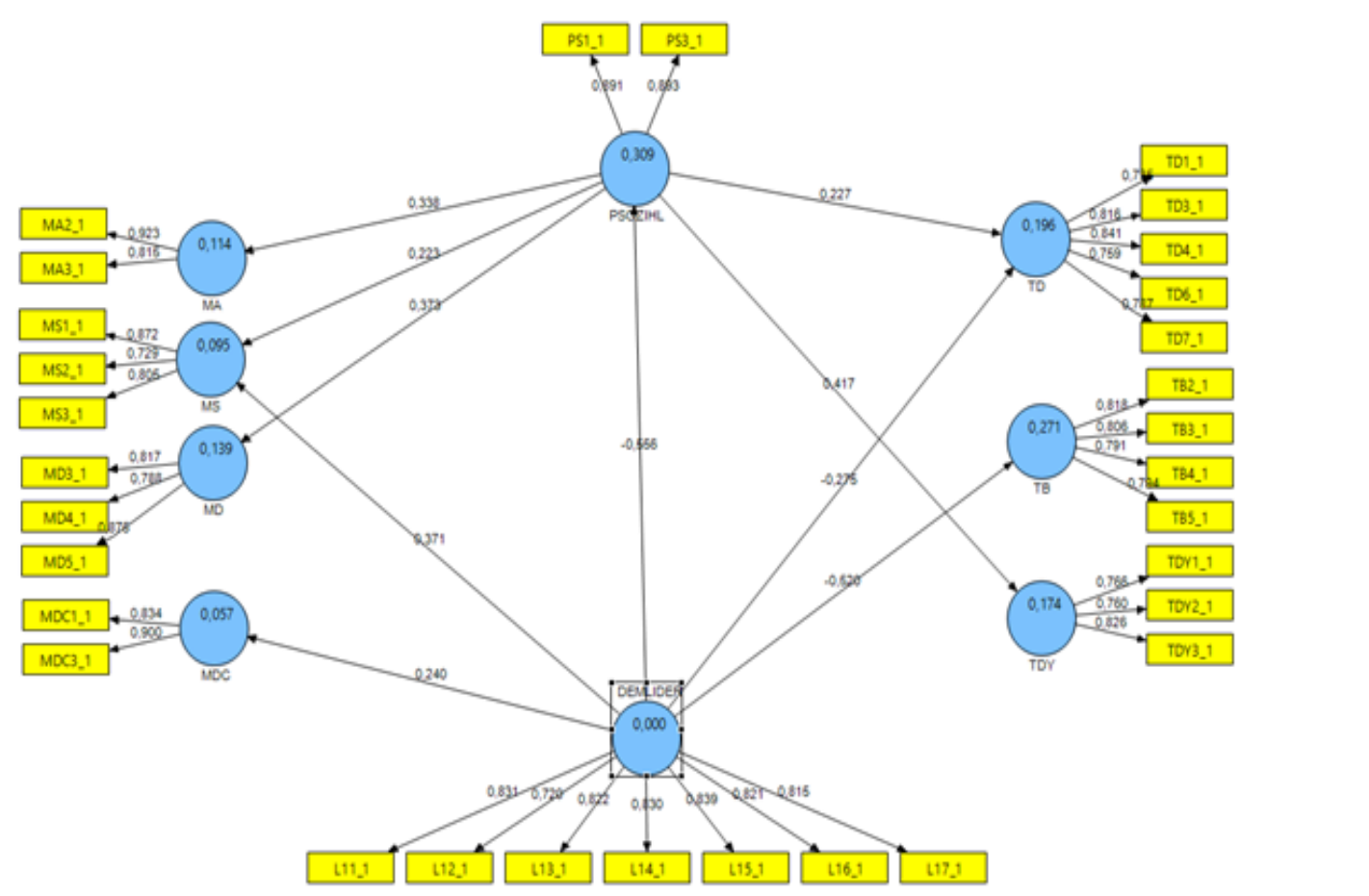

Psikolojik sözleşme ihlalinin ilişkili olduğu makyevelizm ve mesleki tükenmişilğin alt boyutları ile arasındaki ilişkinin pozitif yönlü olduğu görülmektedir. Dolayısıyla psikolojik sözleşme ihlali algısındaki bir artış makyevelist tutumların ve mesleki tükenmişliğin de artmasına neden olabilir. Psikolojik sözleșme ihlali ile liderin demokratlı̆̆ı arasındaki ilișkinin yönü ise negatiftir. Liderin, yönetim esnasında göstereceği demokratik tutum ve davranışlar çalışanların psikolojik sözleşme ihlali algısını zayıflatabilir. Demokratik liderlik ile makyevelizmin alt boyutları arasında ise pozitif yönlü zayıf bir ilişkinin olduğu görülmektedir. Demokratik tutum içerisinde olan liderlerin çalışanların kendi kararlarını almaları yönünde oluşturacakları örgütsel iklim, çalışanları makyevelist tutumlara itebilmektedir. Demokratik liderlik ile mesleki tükenmişliğin duygusal tükenme ve başarısızlık hissi alt boyutları ile ise ilişkinin yönü negatif tespit edilmiştir. Liderlerin demokratik tutumları çalışanların tükenmişlik hislerini azaltabilmektedir. $\mathrm{Bu}$ sonuçlara göre $\mathrm{H} 1, \mathrm{H} 2 \mathrm{a}, \mathrm{H} 2 \mathrm{~b}, \mathrm{H} 2 \mathrm{c}, \mathrm{H} 4 \mathrm{a}, \mathrm{H} 4 \mathrm{c}, \mathrm{H} 5 \mathrm{a}, \mathrm{H} 5 \mathrm{~b}$ hipotezleri doğrulanmıştır. H3b ve H3d hipotezleri ise negatif yönlü olarak doğrulanmıştır. PSİ ile kontrol arzusu ve kişisel başarısızlık hissi arasında ve DL ile ahlaki yoksunluk, diğerlerine güvensizlik ve duyarsızlaşma arasında anlamlı bir ilişki bulunmamıştır.

\section{SONUC}

Satış sektörü, rekabetin yoğun olduğu ve çalışanların psikolojik durum ve tutumlarının başarı üzerinde önemli ölçüde etken olduğu bir sektördür. Yoğun satış baskısı yaşayan çalışanlar aynı zamanda daha çok satış yaparak gelirlerini artırma hedefi de taşıdıklarında, oldukça gergin bir şekilde çalışmalarını sürdürmektedirler. Dolayısıyla gerginliğin kaynağı hem örgütsel hem de iç sebeplerdir. Bu çalışmada da psikolojik sözleşme ihlali ve demokratik liderlik gibi örgütsel faktörlerin yanısıra makyevelizm ve mesleki tükenmişlik gibi bireysel faktörler arasındaki ilişkiler analiz edilmiştir.

Yapılan analizler sonucunda psikolojik sözleşme ihlali ile demokratik liderlik arasında orta düzeyde negatif yönlü $(\mathrm{r}:-0,556)$ anlamlı ilişki bulunmuştur. Liderlerin çalışanlara yönelik tutumları onların yazılı olmayan sözleşmeye yönelik algılarını etkilemektedir. Demokratik tutumların çalışanlarda, sözleşmeye uyulduğu algısına yol açabileceği görülmektedir. Psikolojik sözleşme ihlali algısındaki bir artışı aynı zamanda ahlaki yoksunluk ve statü arzusu üzerinde de artışa neden olabileceğini veya tam tersini söyleyebilmek mümkündür. Zagenczyk vd. (2014) yaptıkları dört farklı çalışmanın tümünde 
makyevelizm ile psikolojik sözleşme ihlali arasında pozitif yönlü anlamlı ilişki tespit etmişlerdir. Makyevelistlik düzeyi yüksek olanlar, daha sinik olma eğilimi göstermektedirler. Bu çalışanlar için, yaşanan psikolojik sözleşme ihlallerinin olumsuz etkilerini hafifletebilmek, işverenin pişmanlık girişimlerine karşı güvensizlikleri nedeniyle daha zor olabilmektedir. Eğer yöneticiler, psikolojik sözleşme ihlalinin, örgütün kontrolünün dışında olduğu veya ihlal için örgütün suçlanamayacağına ikna edebilirlerse, belki de olumsuz sonuçların oluşumunu azaltabilirler (Zagenczyk vd., 2012, s. 296).

Psikolojik sözleşme ihlali aynı zamanda tükenmişlik ile de pozitif yönlü ilişki içerisindedir. Cai ve Ye (2016) psikolojik sözleşmeyi pozitif psikoloji perspektifinden ele alarak yaptıkları çalışmada, psikolojik sözleşme ile mesleki tükenmişlik ve duygusal tükenme arasında negatif yönlü anlamlı ilişki tespit etmişlerdir. Chambel ve Cruz (2010) ise askerlere yönelik yaptıkları çalışmada psikolojil sözleşme ihlali ile tükenmişlik arasında pozitif yönlü anlamlı ilişki bulmuştur. Dolayısıyla bu çalışmanın sonucu literatürle uyumludur. Çalışmanın sonucuna göre psikolojik sözleşme ihlali algısı duygusal tükenmeyi ve duyarsızlaşmayı pozitif yönlü olarak etkilemektedir. Aynı zamanda tükenmişlik yaşayan çalıșanlar işverenle arasındaki sözleşmenin ihlal edildiği algısına da sahip olabilmektedirler. Nitekim demokratik liderlik tutumlarının mesleki tükenmişliği azalttığı görülmektedir. Çalışanların kararlarına verilen değer, onların olumlu duygular hissetmelerine ve dolayısıyla tükenmişliklerinde azalmaya neden olabilmektedir.

Çalışmanın bir diğer boyutunu ise makyevelizm oluşturmaktadır. Satış baskısının çalışanları makyevelist tutuma yöneltmeleri mümkündür. Shultz (1993)' a göre, satış organizasyonlarında kullanılan Makyevelist taktiklerin başarısı veya başarısızlığı organizasyonun yapısına bağlıdır. Nitekim bu çalışmada da demokratik liderlik halinde yani çalışanların daha serbest karar verebilmesi imkanı söz konusu olduğunda, makyevelist tutumların da arttığı görülmektedir. Dolayısıyla örgütler, makyevelist tutumları örgüt hedefleriyle aynı potada eritebildikleri ölçüde bu kişilik özelliğinden karlı çıkabilirler. Bu yüzden makyevelist tutumları her zaman olumsuz değerlendirmekten kaçınmak gerekmektedir. Çalışanlardaki bu farklılıkların iyi yönetilmesi halinde arzulanan örgütsel hedeflere ulaşabilmek daha kolay olacaktır. Örgütsel hedeflere ulaşılması bireysel hedefleri de olumlu yönde etkileyecektir. $\mathrm{Bu}$ durum mesleki tükenmişlik gibi olumsuz durumların gelişmesini önlemeye de katkı sağlayacaktır.

\section{KAYNAKÇA}

Adıgüzel, Z. (2019). Examination of the effects of despotic leadership and strategic human resources management on the employees in the business world. Yönetim ve Ekonomi Araştırmaları Dergisi, 17(1), 143-162.

Ali, F., Rasoolimanesh, S. M., Sarstedt, M., Ringle, C. M., ve Ryu, K. (2018). An assessment of the use of partial least squares structural equation modeling (PLS-SEM) in hospitality research. International Journal of Contemporary Hospitality Management, 30(1), 514-538.

Avşaroğlu S.; Deniz M.E. ve Kahraman A. (2005). Teknik öğretmenlerde yaşam doyumu iş doyumu ve mesleki tükenmişlik düzeylerinin incelenmesi. Selçuk Üniversitesi Sosyal Bilimler Ens. Dergisi, $14,115-129$.

Babakus, E., Yavas, U., ve Ashill, N. J. (2010). Service worker burnout and turnover intentions: Roles of person-job fit, servant leadership, and customer orientation. Services Marketing Quarterly, 32(1), 17-31.

Bagozzi, R.P., ve Yi, Y. (1988). On the evaluation of structural equation models. Journal of the Academy of Marketing Science, 16(1), 74-94.

Bakker A. B., Evangelia Demerouti, Willem Verbeke. (2004). Using the job demands- resources model to predict burnout and performance. Human Resource Management, 43(1), 83-104. 
Bayyurt N. ve Kılıç C.H. (2017). Liderlik tarzının örgüt bağlılığına etkisi: Bir hastane araştırması. İsletme ve İktisat Çalışmaları Dergisi, 5(2), 1-13.

Bobbio, A., Bellan, M., ve Manganelli, A. M. (2012). Empowering leadership, perceived organizational support, trust, and job burnout for nurses: a study in an italian general hospital. Health Care Management Review, 37(1), 77-87.

Cai, X. ve Ye, L. (2016). Psychological contract's mediating effect between psychological capital and job burnout" international conference on logistics, informatics and service sciences (liss), logistics, Informatics and Service Sciences (LISS). 2016 International Conference On, 1. https://doi.org/10.1109/LISS.2016.7854505

Chambel M.J. ve Oliveira-Cruz, F. (2010). Breach of psychological contract and the development of burnout and engagement: A longitudinal study among soldiers on a peacekeeping mission. Military Psychology, 22(2), 110-127.

Dahling, J. J., Whitaker, B. G., ve Levy, P. E. (2008). The development and validation of a new machiavellianism scale. Journal of Management, 35(2), 219-257.

Demir, D. (2018). Bilişim öğretmenlerinin sanal yalnızlık, mesleki tükenmişlik ve psikolojik iyi oluşları arasındaki ilişkinin incelenmesi. Yayımlanmamış yüksek lisans tezi, Afyon Kocatepe Üniversitesi Fen Bilimleri Enstitüsü, Afyon.

Drory A. ve Gluskinosi U.M. (1980). Machiavellianism and leadership. Journal of Applied Psychology, 65(1), 81-86.

Dülgeroğlu, İ., ve Başol, O. (2017). İş stresi ve çalışma yaşamı kalitesi algısının yansımaları: satış temsilcileri üzerine bir araştırma. Business and Economics Research Journal, 8(2), 293-304.

Ece, S. (2019). Hizmetkâr liderlik, işe yönelik tutum ve işten ayrılma niyeti arasındaki ilişki: Şırnak örneği. BMIJ, 7(2), 795-813.

Ercan, A. ve Kazançoğlu İ. (2019). Algılanan örgütsel sinizmin mesleki tükenmişlik olgusuyla ilişkisi: Satış personeli üzerine bir araştırma. Organizasyon ve Yönetim Bilimleri Dergisi, 11(2), 1-19.

Ertürk, E. ve Keçecioğlu T. (2012). Çalışanların iş doyumları ile mesleki tükenmişlik düzeyleri arasındaki ilişkiler: Öğretmenler üzerine örnek bir uygulama. Ege Akademik Bakış, 12(1), 3952 .

Fornell, C., ve Larcker, D.F. (1981). Evaluating structural equation models with unobservable variables and measurement error. Journal of Marketing Research, 18(1), 39-50.

Galie, P.J. ve Bopst C. (2006). Machiavelli \& Modern business: Realist thought in contemporary corporate leadership manuals. Journal of Business Ethics, 65, 235-250.

Gemmill, G., ve Heisler, W. (1972). Machiavellianism as a factor in managerial job strain, job satisfaction, and upward mobility. The Academy of Management Journal, 15(1), 51-62.

Golonka K, Mojsa-Kaja J, Blukacz M, Gawłowska M ve Marek T. (2019). Occupational burnout and its overlapping effect with depression and anxiety. International Journal of Occupational Medicine and Environmental Health, 32(2), 229-244.

Gündüz, B.; Çapri, B. ve Gökçakan Z. (2013). Mesleki tükenmişlik, işle bütünleşme ve iş doyumu arasındaki iliş̧kilerin incelenmesi. Eğitim Bilimleri Araştırmaları Dergisi, 3(1), 29-49.

Güney, S. ve Mandacı G. (2009), Makyavelizm ve etik algısı ilişkileri: Bankacılık sektöründe bir araştırma. H. Ü. Íktisadi ve İdari Bilimler Fakültesi Dergisi, 27(2), 83-104.

Hunsaker, W. D. (2019). Spiritual leadership and job burnout: mediating effects of employee well-being and life satisfaction. Management Science Letters, 9, 1257-1268.

Jackson, M., ve Grace, D. (2018). The science of machiavellianism. in machiavelliana, The Living Machiavelli in Modern Mythologies (Vol. 317). Leiden, The Netherlands: Brill | Rodopi 
Jaiswal, P. ve Bhal, K.T. (2014). Behavioural flexibility: The use of upward impression management tactics by subordinates for good performance rating from leader and impact of organizational \& leader's machiavellianism. Global Journal of Flexible Systems Management, 15(4), 313-326.

Koçel, T. (2005), İsletme yöneticiliği. İstanbul: Beta Yayınları.

Kroger, J., Segovia, J., Sallee, L., ve Lenard, C. (2015). Machiavellianism in business management and corporations. Academy of Business Research Journal, 4(2), 80-87.

Küçüközkan, Y. (2015). Liderlik ve motivasyon teorileri: Kuramsal bir çerçeve. Uluslararası Akademik Yönetim Bilimleri Dergisi, 1(2), 85-116.

Kwong, K., ve Wong, K. (2013). Partial least squares structural equation modeling (PLS-SEM) techniques using smartPLS. Marketing Bulletin, 24(Technical Note 1).

Lyberg, L., Biemer, P., Collins, M., De Leeuw, E., Dippo, C., Schwarz, N., ve Trewin, D. (1997). Survey measurement and process quality. New York: Wiley.

Maslach, C. ve Susan E. J. (1981). The measurement of experienced burnout. Journal of Occupational Behaviour, 2, 99-113.

Mirkovic, D., ve Bianchi, R. (2019). An exploratory study of the link between machiavellianism and burnout. Personality and Individual Differences, 148, 27-31.

Morrison, E., Robinson, S. L. (1997). When employees feel betrayed: A model of how psychological contract violation develops. The Academy of Management Review, 22(1), 226-256.

Özsoy, E., ve Ardıç, K. (2017). Karanlık Üçlü’nün (narsisizm, makyavelizm ve psikopati) iş tatminine etkisinin incelenmesi. Yönetim ve Ekonomi, 24(2), 391-406.

Peterson, R. A., ve Kim, Y. (2013). on the relationship between coefficient alpha and composite reliability. Journal of Applied Psychology,98(1), 194-8.

Polat S. ve Uğurlu C.T. (2009). İlköğretim müfettişlerinin örgütsel bağl1lık, mesleki tükenmişlik ve işten ayrılma niyetleri arasındaki ilişki. e-Journal of New World Sciences Academy, 4(3), 1150-1159.

Rehman U. ve Shahnawaz, M.G. (2018). Machiavellianism, job autonomy, and counterproductive work behaviour among indian managers. Journal of Work and Organizational Psychology, 34(2), 8388 .

Rousseau, D. M. (1989). Psychological and implied contracts in organizations. Employee Responsibilities and Rights Journal, 2, 121-139.

Rousseau, D. M. (1995). Psychological contracts in organizations: Understanding written and unwritten agreements. Thousand Oaks, CA: SAGE.

Sakalaki, M.; Richardson, C. ve Thepaut, Y. (2007). Machiavellianism and economic opportunism, Journal of Applied Social Psychology, 37(6), 1181-1190.

Salem I. (2015). Transformational leadership: Relationship to job stress and job burnout in five-star hotels. Tourism and Hospitality Research, 15(4), 240-253.

Salha, H.; Cinnioğlu H. ve Yazıt, H. (2016). Psikolojik sözleşme ihlal algısının tükenmişlik üzerine etkisi: Yiyecek içecek işletmeleri üzerine bir araştırma. 17. Ulusal Turizm Kongresi, Muğla

Shelby D. ve Chonko L.B. (1984). Marketing and machiavellianism. Journal of Marketing, 48, 30-42.

Shultz, C. J. (1993). Situational and dispositional predictors of performance: A test of the hypothesized machiavellianism x structure interaction among sales persons. Journal of Applied Social Psychology, 26(6), 478-498.

Sürgevil, O. (2006), Çalışma hayatında tükenmişlik sendromu. Ankara: Nobel Yayın. 
Telli, E., Ünsar, A. S., ve Oğuzhan, A. (2012). Liderlik davranış tarzlarının çalışanların örgütsel tükenmişlik ve işten ayrılma eğilimleri üzerine etkisi: Konuyla ilgili bir uygulama. Electronic Journal of Vocational Colleges, 2(2), 135-150.

Ülbeği, İ.D. (2016). Makyavelizm ölçeğinin güvenirlik ve geçerlik çalışması. Ç.Ü. Sosyal Bilimler Enstitüsü Dergisi, 25(2), 89-100.

Zagenczyk, T. J., Cruz, K. S., Woodard, A. M., Walker, J. C., Few, W. T., Kiazad, K., ve Raja, M. (2012). The Moderating effect of machiavellianism on the psychological contract breachorganizational identification/disidentification relationships. Journal of Business and Psychology, 28(3), 287-299. 